\title{
Intracellular calcium response to hydraulic pressure in human trabecular cells
}

\author{
Toshihiko Matsuo, Nobuhiko Matsuo
}

\begin{abstract}
Aims-To understand the mechanism for regulation of intraocular pressure, human trabecular cells were examined to determine whether they could respond to the change in hydraulic pressure.

Methods-Human trabecular cells were cultured from trabeculum tissue fragments excised during trabeculectomy in four eyes of three patients with primary open angle glaucoma and exposed to the change of hydraulic pressure in a tissue culture flask connected to a glass syringe. The pressure was exerted by automatic infusion of the piston of the syringe and monitored by a pressure gauge. The intracellular calcium concentration was measured in real time with a calcium binding fluorescent dye, fluo-3.
\end{abstract}

Results-A small number (about $10 \%$ ) of cells appearing morphologically to be trabecular cells showed transient elevations or oscillations of the intracellular calcium concentration in response to the elevation of hydraulic pressure to $20-30 \mathrm{~mm} \mathrm{Hg}$, indicating that a part of the human trabecular cells could sense the change in hydraulic pressure.

Conclusion-Some cells in the human trabecular tissue seem to sense the change in intraocular pressure and might play a role in its regulation.

(Br F Ophthalmol 1996;80:561-566)

Trabecular meshwork is a major site for aqueous outflow and its abnormalities lead to the elevation of intraocular pressure. ${ }^{12}$ Cells covering beams of the trabecular meshwork and in the juxtacanalicular tissue near the Schlemm's canal are referred to as trabecular cells which naturally consist of heterogeneous populations. ${ }^{3-5}$ The trabecular cells produce various kinds of biologically active substances as growth factors ${ }^{6}$ and prostaglandins, ${ }^{78}$ and also synthesise extracellular matrix compo-

Department of Ophthalmology, Okayama University Medical School, Okayama City, Japan T Matsuo N Matsuo

Correspondence to: Dr Toshihiko Matsuo Department of Ophthalmology, Okayama University Medical School, 2-5-1 Shikata-cho, Okayama City, Okayama 700, Japan.

Accepted for publication

7 February 1996 nents, ${ }^{9-11}$ indicating that they play a role in physiological homeostasis of the trabecular meshwork as well as in maintaining its anatomical architecture.

Intraocular pressure (IOP) is maintained by the balance between the production of aqueous humour by the ciliary epithelium and its outflow, mainly at the trabecular meshwork but also by the uveoscleral route. However, it is not known how the IOP is maintained in a normal range and whether there is a sensing mechanism for IOP. In addition to the previous observations of many nerve endings in the trabecular meshwork, ${ }^{12}$ Tamm et al ${ }^{13}$ recently

showed by electron microscopy the presence of nerve endings characteristic of mechanoreceptors in the scleral spur, supporting the old hypothesis that the central nervous system is involved in the regulation of IOP. ${ }^{14-20}$ We previously demonstrated that cyclic mechanical stretching of cultured bovine and porcine trabecular cells resulted in their increased production of prostaglandin $\mathrm{F}_{2 \alpha}{ }^{21}$ and suggesting that they sensed the pressure. In this study, we developed an in vitro model system to exert controlled hydraulic pressure on cultured cells and demonstrated that intracellular calcium concentration in human trabecular cells could change in response to the elevation of hydraulic pressure.

\section{Materials and methods}

CULTURE OF HUMAN TRABECULAR CELLS ${ }^{22-25}$

Trabeculum tissue fragments excised during trabeculectomy in patients with primary open angle glaucoma were placed in wells of a 24 well multidish (Nunc, Naterville, IL, USA) containing Dulbecco's modified Eagle's medium (DMEM) supplemented with $15 \%$ fetal calf serum, $100 \mu \mathrm{g} / \mathrm{ml}$ streptomycin, and 100 $\mu \mathrm{g} / \mathrm{ml}$ ampicillin and incubated under a humidified atmosphere of $5 \%$ carbon dioxide and $95 \%$ air at $37^{\circ} \mathrm{C}$. Cells grew out of the tissue fragments obtained from three eyes of four patients (Table 1) usually 2 weeks after the start of culture. Cells were then dislodged by 5 minute treatment with $0.25 \%$ trypsin and 1 mM EDTA in Hanks' balanced salt solution (Gibco BRL, Grand Island, NY, USA), and transferred to a six well multidish (Nunc) and then to a $10 \mathrm{~cm}$ petri dish (Nunc). The second to fourth passage of cells were used for the following experiments.

ELECTRON MICROSCOPIC OBSERVATION OF CULTURED CELLS ${ }^{26}$

Cells dispersed by treatment with $0.25 \%$ trypsin and $1 \mathrm{mM}$ EDTA for 5 minutes were transferred to a 24 well multiplate for suspension culture (Sumilon, Tokyo, Japan) and incubated for 1 month in DMEM supplemented with $15 \%$ fetal calf serum. Media were changed twice a week. Cells formed floating

Table 1 Rates of response to hydraulic pressure in Table 1 Rates of response to hydraulic with primary open trabecular cells der

\begin{tabular}{ll}
\hline $\begin{array}{l}\text { Patient No/age (years)/ } \\
\text { sex/laterality }\end{array}$ & $\begin{array}{l}\text { No of responding cells/No of } \\
\text { cells observed }\end{array}$ \\
\hline 1/70/female/right & $5 / 52(9.6 \%)$ \\
$1 / 70 /$ female/left & $8 / 78(10.3 \%)$ \\
2/70/male/left & $6 / 49(12.2 \%)$ \\
3/60/male/right & $0 / 45(0 \%)$ \\
\hline
\end{tabular}



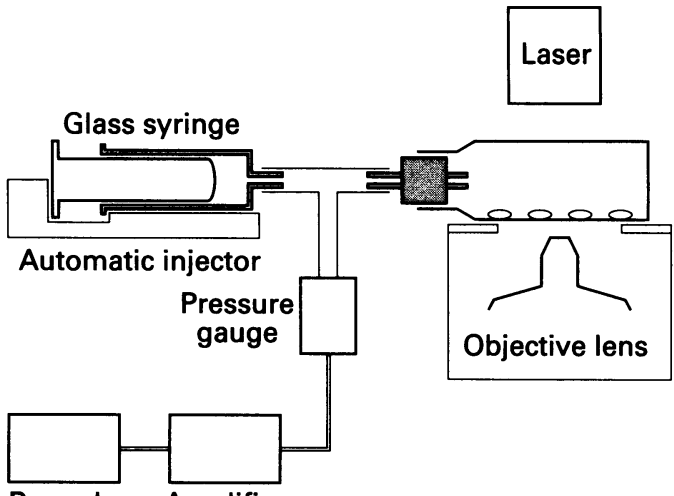

Recorder Amplifier

Figure 1 Schematic diagram showing a system tò exer controlled hydraulic pressure on cultured cells and to measure simultaneously their intracellular calcium concentration. The pressure in a flask filled with medium can be elevated by automatic movement of the piston of $a$ syringe and monitored by an electric pressure gauge.

aggregates (multicellular spheroids) within a day under this non-adherent environment of culture. $^{27-32}$ Multicellular spheroids after 1 month were fixed with $2.5 \%$ glutaraldehyde in
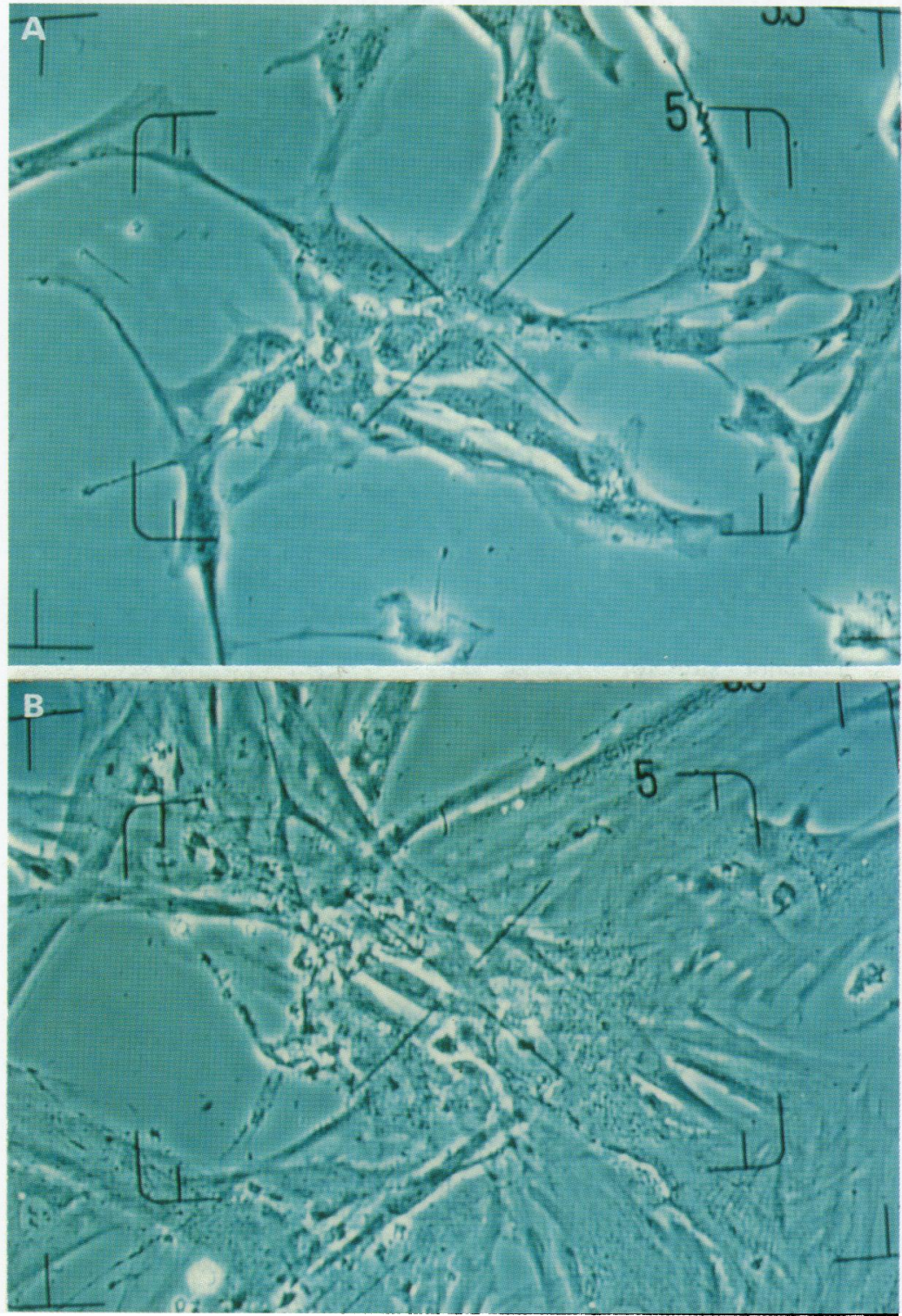

Figure 2 Phase contrast micrographs of cells used in this study (derived from the right eye in patient 1). The predominant type of cells $(A)$ are star-shaped, have multiple cellular processes, and grow in a monolayer, characteristic of human trabecular cells. ${ }^{22-25}$ The other type of cells observed occasionally as small foci in culture are spindle-shaped, and grow in superimposed layers, characteristic of scleral fibroblasts or keratocytes. ${ }^{22-25}$ Magnification, $\times 50$.
$0.1 \mathrm{M}$ phosphate buffer ( $\mathrm{pH} 7 \cdot 4$ ), then with $1 \%$ osmium tetroxide, dehydrated with a graded alcohol series, and embedded in epoxy resin. Ultrathin sections were cut and stained with uranyl acetate and lead citrate. We used multicellular spheroids for morphological observation of the cells because cells, in general, showed more tendency to differentiate in multicellular spheroids than in monolayer growth. ${ }^{28-3032}$

APPLICATION OF HYDRAULIC PRESSURE AND MEASUREMENT OF INTRACELLULAR CALCIUM CONCENTRATION

Human trabecular cells were transferred to tissue culture polystyrene flasks with an area of $25 \mathrm{~cm}^{2}$ (Iwaki, Funabashi, Japan) and cultured for 4 days. The cells before reaching confluency were loaded with $10 \mu \mathrm{M}$ of fluo-3 acetoxymethyl ester (fluo-3/AM: Molecular Probe, Eugene, OR, USA) for 30 minutes at $37^{\circ} \mathrm{C}$ in DMEM and incubated further in DMEM without fluo-3/AM. ${ }^{33}{ }^{34}$ The flask was then filled with HEPES buffered saline (10 mM HEPES, $145 \mathrm{mM} \mathrm{NaCl}, 5 \mathrm{mM} \mathrm{KCl}, 1$ $\mathrm{mM} \mathrm{MgCl} 2,1 \mathrm{mM} \mathrm{CaCl}_{2}$, and $10 \mathrm{mM}$ glucose, $\mathrm{pH} 7.4){ }^{35}$

The flask was placed on the stage of an inverted microscope (Olympus IMT-2: Olympus, Tokyo, Japan) attached to argon ion laser (laser scanning microspectrofluorometer ACAS570, Meridian Instruments, Okemos, MI, USA), and hydraulic pressure was exerted on the cells as shown schematically in Figure 1. The pressure inside the flask was elevated by controlled movement of the piston of a $10 \mathrm{ml}$ glass syringe connected to the flask, by means of an automatic syringe injector (Syringe Infusion Pump, Model 980324, Harvard Apparatus, South Natick, MA, USA), and monitored continuously by a pressure gauge (LifeKit, Disposable Pressure Monitoring Kit: Nihon Kohden, Tokyo) connected through an amplifier (RMP-6004M: Nihon Kohden) to a printer (Mini Recorder SJ-3462: Atto, Tokyo, Japan).

The changes in intracellular calcium concentration of trabecular cells were observed as the changing intensity of fluorescence every 20 seconds. The fluorescent images of cells visualised by scanning argon laser at $488 \mathrm{~nm}$ as an excitation wavelength were captured through a $\times 20$ objective lens by a photomultiplier tube and stored on a computer. One frame of the image usually contained 3-7 cells and the fluorescent intensity of each cellular area was measured by an image analysis program in Single Detector Kinetics Program Version 3.22 (Meridian).

\section{Results}

MORPHOLOGICAL CHARACTERISTICS OF CELLS Cells could be grown out of about a half of trabecular explants tested and consisted apparently of two types of cells. The dominant type had a star-like or triangular shape with multiple cell processes and showed monolayer growth in confluency (Fig 2A), indicating the features of trabecular cells. ${ }^{22-25}$ The other type, which was observed less frequently, were elon- 


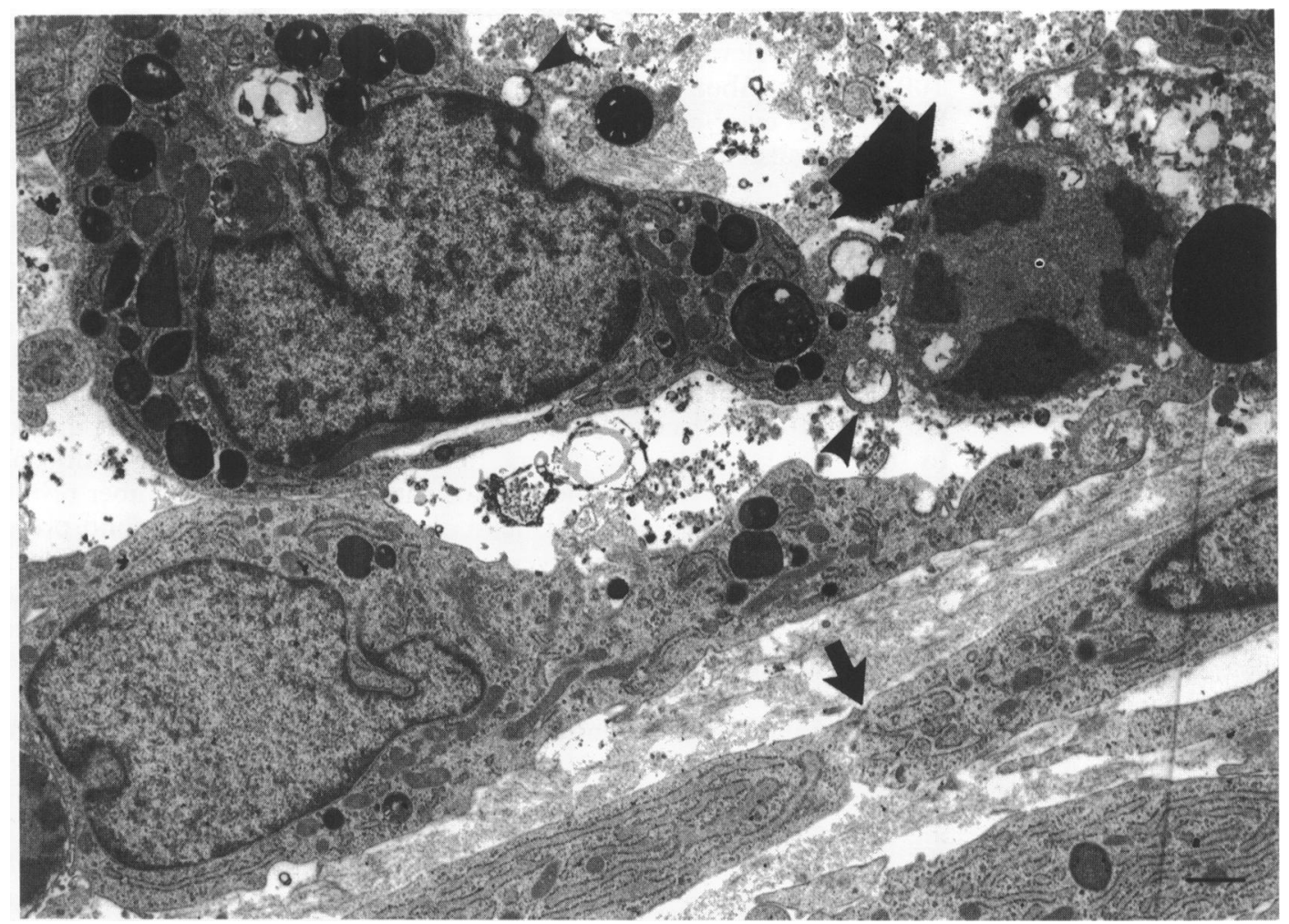

Figure 3 Electron micrograph of cells used in this study (derived from the right eye in patient 1). Cells grown as a multicellular spheroid in a non-adherent environment for 1 month ${ }^{26}$ have nuclei with the dark spiked band of peripheral chromatin, osmiophilic cytoplasm with various organelles, together with many villous projections and coated vesicles (arrowheads) along the cell surface, characteristic of human trabecular cells. ${ }^{23-25}$ An apoptotic cell (arge arrow) is phagocytosed by a neighbouring trabecular cell and an intercellular junction is noted between cellular processes (small arrow). Uranyl acetate and lead citrate staining. Bar $=1 \mu \mathrm{m}$.

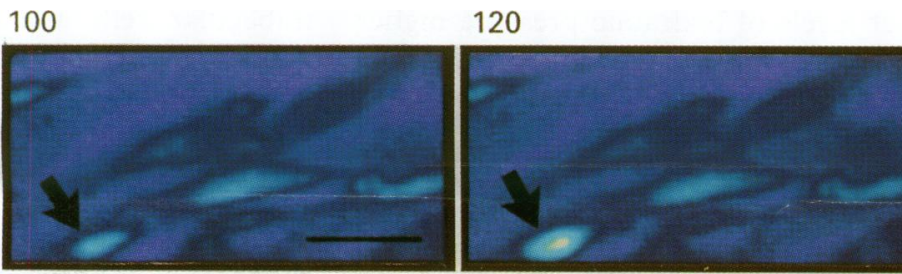

160

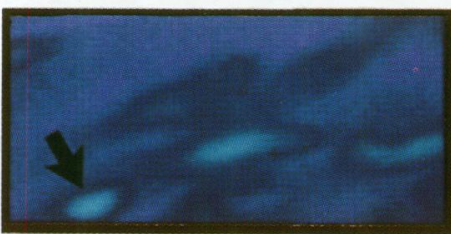

220

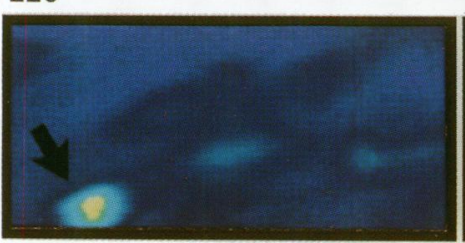

180

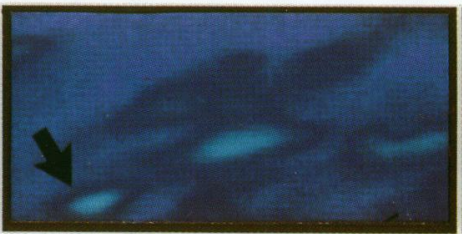

240

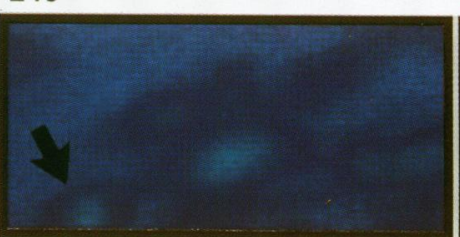

140

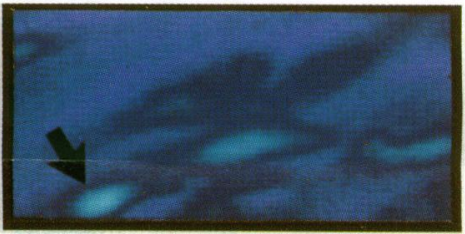

200

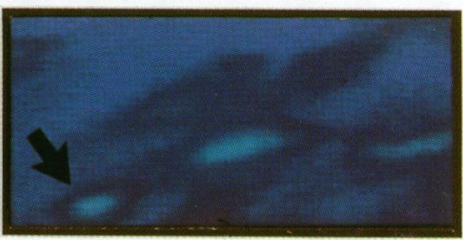

260 seconds

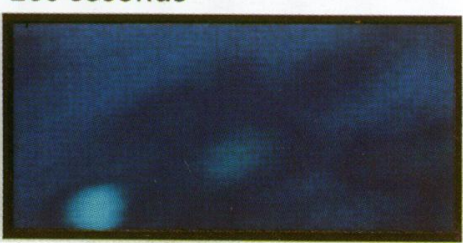

Figure 4 Transient elevations (oscillations) of the intracellular calcium concentration in a trabecular cell (arrows) in response to the elevation of hydraulic pressure. The responding cell shows the increased intensity of fluorescence represented as pseudocolours in a time course. Downward trends of fluorescence intensity in each cell as a lapse of time are due to defocusing of the image caused by expansion of the flask. Bar $=50 \mu \mathrm{m}$.

gated, spindle-shaped cells that grew in superimposed layers as small foci (Fig 2B), characteristic of scleral fibroblasts or keratocytes. ${ }^{22-25}$

Electron microscopically, cells in multicellular spheroids 1 month after the beginning of culture showed many villous projections and coated vesicles along the cell surface, together with frequent intercellular junctions (Fig 3).
The osmiophilic cytoplasm contained various organelles such as ribosomes, mitochondria, Golgi apparatus, and different levels of phagosomes, while the nuclei showed the prominent dark spiked band of peripheral chromatin. All these features were consistent with those described for human trabecular cells in culture. $^{23-25}$ 
RESPONSE TO HYDRAULIC PRESSURE

Hydraulic pressure exerted on human trabecular cells was elevated continuously from 0 to $100 \mathrm{~mm} \mathrm{Hg}$. About $10 \%$ of the cells derived from three eyes of two patients (Table 1) showed transient elevation (transients) or oscillations (a group of transients) of intracellular calcium concentration at a hydraulic pressure over $20 \mathrm{~mm} \mathrm{Hg}$ (Figs 4 and 5). The threshold levels of hydraulic pressure to induce transients of intracellular calcium varied from cell to cell and ranged between 20 and $30 \mathrm{~mm}$ $\mathrm{Hg}$. These transients of intracellular calcium lasted for 40 to 80 seconds and then returned to the same baseline level as before the transients. The peaks of these transients as fluorescent intensity were at least 1.5-fold higher than the baseline level. Downward trends of the baseline level of fluorescent intensity as a lapse of time seen in Figure 5 were due to defocusing of the images caused by expansion of the flask.

The baseline levels of intracellular calcium in the responding cells were similar to those in the non-responding cells (Fig 4). The responding cells belonged morphologically to trabecular cells rather than fibroblasts or keratocytes. The morphological difference between the responding and non-responding cells was not evident. Spindle-shaped cells growing in superimposed layers as small foci considered to be fibroblasts or keratocytes did not show any response to the elevation of hydraulic pressure.

The number of responding cells did not increase at levels of hydraulic pressure higher than $20 \mathrm{~mm} \mathrm{Hg}$. Non-responding cells remained non-responsive at the higher levels of pressure up to $150 \mathrm{~mm} \mathrm{Hg}$. The mainten-


Figure 5 Time course of intracellular calcium concentration as shown by fluorescence intensity and the level of hydraulic pressure. Transient elevation of the intracellular calcium concentration ( $A$, transient) is observed at $20 \mathrm{~mm} \mathrm{Hg}$ in one trabecular cell, while a group of transients (B, oscillations) started at $20 \mathrm{~mm} \mathrm{Hg}$ in another cell (corresponding to the cel (arrow) shown in Figure 4). ance of hydraulic pressure at $0 \mathrm{~mm} \mathrm{Hg}$ for 10 minutes, as a control, did not induce transients or oscillations of intracellular calcium. Cells derived from one patient (Table 1) did not show any response to hydraulic pressure.

\section{Discussion}

In the system we developed, hydraulic pressure exerted on cells in culture could be changed both at a level of $\mathrm{mm} \mathrm{Hg}$ and in a time span of seconds, and monitored continuously with an electric pressure gauge. Systems used by others simply involved putting a load on the layer of cells growing at the bottom of culture dishes ${ }^{36}$ or elevating atmospheric pressure in the culture chamber resulting in the transfer of air pressure to fluid pressure. ${ }^{37}$ In these systems, real hydraulic pressure to which cells were exposed could not be measured or monitored, although rough values for pressure could be calculated.

Our system utilised a closed chamber filled with fluid which was not circulated or exposed to air. Therefore, the limited supply of oxygen to the cells was a major drawback. We finished the experiments within 30 minutes after the flasks with cultured cells in medium were taken out of an incubator and filled with fluid for measuring intracellular calcium. These flasks had a volume of $60 \mathrm{ml}$, and this contained enough oxygen for a small number of cells during this short period.

Intracellular calcium has been shown to play a role as a second messenger in bovine trabecular cells and mediate the stimuli by cholinergic and adrenergic ligands as well as neuropeptides. ${ }^{38}{ }^{39}$ The oscillations of intracellular calcium in human trabecular cells in this study could be observed only under the change of hydraulic pressure and would be mediated by mechanosensitive (stretch activated) ion channels. ${ }^{40}{ }^{41}$ These channels would be gated directly for calcium ions or other ions, ${ }^{42}$ and calcium oscillations could result from a combination of calcium flowing from the calcium storage in the cells and outside the cells. ${ }^{43}{ }^{44}$ The elevation of intracellular calcium, as a second messenger, then causes a variety of cellular responses such as synthesis and secretion of biological signals, proliferation, and differentiation. ${ }^{45}$ The calcium oscillations might also induce contraction of trabecular cells since some cells in the human trabecular meshwork were shown by immunohistochemistry to have smooth muscle myosin and actin. 4647

The threshold of hydraulic pressure to induce the transients of intracellular calcium ranged from 20 to $30 \mathrm{~mm} \mathrm{Hg}$ in human trabecular cells used in this study. In contrast, the threshold of pressure for intracellular calcium response in human periodontal ligament fibroblasts examined in the same system ranged widely from 20 to $50 \mathrm{~mm} \mathrm{Hg}$. ${ }^{48}$ In these two types of cells, the elevation of pressure did not lead to such increased responses as more frequent transients of intracellular calcium and their higher peaks. In another study, human gingival fibroblasts did not show oscillations of intracellular calcium at $1 \%$ stretch of cells, but 
did show oscillations at $2.8 \%$ stretch. $^{49}$ These facts suggest that different types of cells have different ranges of the threshold for the response to pressure and that pressure within these ranges generates the constant response. Further studies are necessary to obtain a definite value for the threshold, based on molecular characteristics of putative mechanosensitive ion channels involved in the response to hydraulic pressure in human trabecular cells.

It should be noted that only a limited number of human trabecular cells responded to the elevation of hydraulic pressure. This can be explained by the presence of different subpopulations in the trabecular cells as reported previously. ${ }^{3-5}$ In addition, the cultured cells used in this study would contain different types of cells, since these cells grew out of the trabeculum tissue excised during trabeculectomy, which consisted not only of trabecular cells but also of scleral fibroblasts, keratocytes, and endothelial cells of the Schlemm's canal. However, the present study demonstrated that the responding cells belonged morphologically to trabecular cells, and that fibroblasts or keratocyte-like cells did not show any response to hydraulic pressure. Another possibility is that the non-responsive cells might utilise a different second messenger system other than calcium in their responses to pressure, which naturally could not be detected as a positive response in this study.

Our present finding that trabecular cells themselves could respond to the change in hydraulic pressure within a physiological range suggests another way for regulation of the IOP, in addition to its regulation by nerve endings in the trabecular meshwork and scleral spur. ${ }^{12}{ }^{13}$ The trabecular cells could sense the change in the IOP and modify their function to facilitate outflow at the trabecular meshwork. ${ }^{50}$ They might also secrete paracrine signals which diffuse in the aqueous to the ciliary epithelium. Our previous result that cyclic mechanical stretching increased the production of prostaglandin $F_{2 \alpha}$ by trabecular cells ${ }^{21}$ gave us a hypothesis-namely, that trabecular cells responding to the elevation of IOP secrete prostaglandin $F_{2 \alpha}$ as a paracrine signal which facilitates the uveoscleral outflow. ${ }^{51}$

The response of intracellular calcium to mechanical stress has been well studied, especially in vascular endothelial cells which are exposed in vivo to the changing stress of blood flow. ${ }^{52-57}$ The vascular endothelial cells in culture were subjected to mechanical shearing force or stretching. Trabecular cells in the eye are also exposed to the aqueous flow and hydraulic pressure as well as mechanical stretching induced by the deformation of trabecular meshwork. The architecture of meshwork is more easily deformed by subtle changes in the flow and hydraulic pressure than the rigid structure. This may be the reason why the outflow site at the angle is formed as a meshwork in the eye.

In conclusion, human trabecular tissue contained a small group of cells capable of responding to the elevation of hydraulic pressure, suggesting that these cells play a role in sensing the level of IOP. Abnormalities or loss of these pressure sensitive cells might be related to the development of glaucoma. The number of cells in the trabecular meshwork decreases with age and this decrease is more marked in patients with primary open angle glaucoma. ${ }^{58}$ Such loss of cells $^{5}$ including pressure sensitive cells might underlie the absence of response to hydraulic pressure in trabecular cells derived from the one eye in this study with primary open angle glaucoma.

The authors thank Dr Mariko Fujishita and Takuya Kokubun in Meridian Instruments Far East, Tokyo, and Mr Masahiro Shikano at the Okayama Branch of Nihon Kohden, for thei advice. Some of the experiments were done in the Centra Research Laboratory in Okayama University Medical School.

1 Bill A. Some aspects of aqueous humour drainage. Eye 1993;7:14-9.

2 Rohen JW. Why is intraocular pressure elevated in chronic simple glaucoma? Anatomical considerations. Ophthalmol ogy 1983;90:758-65.

3 Coroneo MT, Korbmacher C, Flugel C, Stiemer B, LutenDrecoll E, Wiederholt M. Electrical and morphological evidence for heterogeneous populations of cultured bovine trabecular meshwork cells. Exp Eye Res 1991;52:375-88.

4 Lepple-Wienhues A, Rauch R, Clark AF, Grassmann A, Berweck S, Wiederholt M. Electrophysiological properties of cultured human trabecular meshwork cells. Exp Eye Res of cultured human

5 Stamer WD, Seftor REB, Williams SK, Samaha HAM, Snyder RW. Isolation and culture of human trabecula meshwork cells by extracellular matrix digestion. Curr Eye Res 1995;14:611-7.

6 Tripathi RC, Borisuth NSC, Li J, Tripathi BJ. Growth factors in the aqueous humor and their clinical significance. F Glaucoma 1994;3:248-58.

7 Weinreb RN, Mitchell MD, Polansky JR. Prostaglandin production by human trabecular cells. In vitro inhibition by

8 Weinreb RN, Polansky JR, Alvarado JA, Mitchell MD. Arachidonic acid metabolism in human trabecular meshArachidonic acid metabolism in human trabecular mesh

9 Schachtschabel DO, Bigalke B, Rohen JW. Production of glycosaminoglycans by cell cultures of the trabecular meshwork of the primate eye. Exp Eye Res 1977;24:71-80

10 Polansky JR, Wood IS, Maglio MT, Alvarado JA. Trabecular meshwork cell culture in glaucoma research: evaluation of biological activity and structural properties of human trabecular cells in vitro. Ophthalmology 1984;91:580-95.

11 Hernandez MR, Weinstein BI, Schwartz J, Ritch R, Gordon GG, Southren AL. Human trabecular meshwork cells in culture: morphology and extracellular matrix components. Invest OphthalmolVis Sci 1987;28:1655-60.

12 Stone RA, Kuwayama Y. The nervous system and intraocular pressure. In: Ritch $R$, Shields MB, Krupin T, eds. The lar pressure. In: Ritch R, Shields MB, Krupin
glaucomas. St Louis: CV Mosby, 1989:257-79.

13 Tamm ER, Flugel C, Stefani FH, Lutjen-Drecoll E. Nerve endings with structural characteristics of mechanoreceptors in the human scleral spur. Invest Ophthalmol Vis $S_{c}$ 1994;35:1157-66.

14 von Sallmann L, Lowenstein O. Responses of intraocular pressure, blood pressure, and cutaneous vessels to electric stimulation in the diencephalon. Am 7 Ophthalmol 1955; 39(Pt II):11-29.

15 Gloster J, Greaves DP. Effect of diencephalic stimulation upon intra-ocular pressure. $\mathrm{Br} \mathcal{F}$ Ophthalmol 1957;41:51332 .

16 von Sallmann L, Fuortes MGF, Macri FJ, Grimes P. Study of afferent electric impulses induced by intraocular pressure changes. Am f Ophthalmol 1958;45(Pt II):211-20.

17 Lele PP, Grimes PA. The role of neural mechanisms in the regulation of intraocular pressure in the cat. Exp Neurol 1960;2:199-220.

18 Perkins ES. Sensory mechanisms and intraocular pressure. Exp Eye Res 1961;1:160-7.

19 Belmonte C, Simon J, Gallego A. Effects of intraocular pressure changes on the afferent activity of ciliary nerves. Exp Eye Res 1971;12:342-55.

20 Zuazo A, Ibanez J, Belmonte C. Sensory nerve responses elicited by experimental ocular hypertension. Exp Eye Res 1986;43:759-69.

21 Matsuo T, Uchida $H$, Matsuo N. Bovine and porcine trabecular cells produce prostaglandin F2alpha in response to cular cells produce prostaglandin F2alpha in response to press).

22 Polansky JR, Weinreb RN, Baxter JD, Alvarado J. Human trabecular cells. I. Establishment in tissue culture and growth characteristics. Invest Ophthalmol Vis Sci 1979;18: 1043-9.

23 Alvarado JA, Wood I, Polansky JR. Human trabecular cells. II. Growth pattern and ultrastructural characteristics. Invest Ophthalmol Vis Sci 1982;23:464-78.

24 Tripathi RC, Tripathi BJ. Human trabecular endothelium, corneal endothelium, keratocytes, and scleral fibroblasts in primary cell culture. A comparative study of growth 
characteristics, morphology, and phagocytic activity by light and scanning electron microscopy. Exp Eye Res 1982 35:611-24.

25 Grierson I, Marshall J, Robins E. Human trabecular meshwork in primary culture: a morphological and autoradiographic study. Exp Eye Res 1983;37:349-65.

26 Matsuo T, Matsuo N. Apoptosis regulated by growth factors in multicellular spheroids of trabecular cells. $f p n f$ Ophthalmol 1996;40: (in press).

27 Moscona A. Rotation-mediated histogenetic aggregation of dissociated cells. A quantifiable approach to cell interactions in vitro. Exp Cell Res 1961;22:455-75.

28 Steinberg MS. Reconstruction of tissues by dissociated cells. Science 1963;141:401-8.

29 DeLong GR. Histogenesis of fetal mouse isocortex and hippocampus in reaggregating cell cultures. Dev Biol 1970;22 563-83.

30 Trapp BD, Honegger P, Richelson E, Webster HD. Morphological differentiation of mechanically dissociated fetal rat brain in aggregating cell cultures. Brain Res 1979;160:11730.

31 Mueller-Klieser W. Multicellular spheroids. A review on cellular aggregates in cancer research. $₹$ Cancer Res Clin Oncol 1987;113:101-22.

32 Koide N, Sakaguchi K, Koide Y, Asano K, Kawaguchi M, Matsushima $\mathrm{H}$, et al. Formation of multicellular spheroids composed of adult rat hepatocytes in dishes with positively charged surfaces and under other nonadherent environments. Exp Cell Res 1990;186:227-35.

33 Minta A, Kao JPY, Tsien RY. Fluorescent indicators for cytosolic calcium based on rhodamine and fluorescein chromophores. 7 Biol Chem 1989;264:8171-8.

34 Kao JPY, Harootunian AT, Tsien RY. Photochemically generated cytosolic calcium pulses and their detection by generated cytosolic calcium pulses and

35 Merritt JE, McCarthy SA, Davies MPA, Moores KE. Use of fluo-3 to measure cytosolic $\mathrm{Ca}^{2+}$ in platelets and fluo-3 to measure cytosolic $\mathrm{Ca}^{2+}$ in

36 Kanai K, Nohara H, Hanada K. Initial effects of continuously applied compressive stress to human periodontal ligament fibroblasts. Nippon Kyosei Shika Gakka Zasshi (f Jpn Orthod Soc) 1992;51:153-63.

37 Yousefian J, Firouzian F, Shanfeld J, Ngan P, Lanese R Davidovitch Z. A new experimental model for studying the response of periodontal ligament cells to hydrostatic pressure. Am f Orthod Dentofac Orthop 1995;108:402-9.

38 Tanihara H, Ohuchi T, Yoshimura N, Negishi M, Ito S. Heterogeneous response in calcium signaling by adrenergic and cholinergic stimulation in cultured bovine cells. Exp Eye Res 1991;52:393-6.

39 Ohuchi T, Tanihara H, Yoshimura N, Kuriyama S, Ito S Honda Y. Neuropeptide-induced $\left[\mathrm{Ca}^{2+}\right] \mathrm{i}$ transients in cultured bovine trabecular cells. Invest Ophthalmol Vis $S c i$ 1992;33:1676-84.

40 Morris CE. Mechanosensitive ion channels. 7 Membrane Biol 1990;113:93-107.
41 Sackin H. Mechanosensitive channels. Annu Rev Physiol 1995;57:333-53.

42 Tsien RW Calcium channels, stores, and oscillations. Annu Rev Cell Biol 1990;6:715-60.

43 Berridge MJ, Irvine RF. Inositol phosphates and cell signalling. Nature 1989;341:197-205.

44 Berridge MJ. Calcium oscillations. $f$ Biol Chem 1990;265: 9583-6.

45 Berridge MJ. Inositol trisphosphate and calcium signalling. Nature 1993;361:315-25.

46 De Kater AW, Spurr-Michaud SJ, Gipson IK. Localization of smooth muscle myosin-containing cells in the aqueous of smooth muscle myosin-containing cells in the aqueous

47 De Kater AW, Shahsafaei A, Epstein DL. Localization of smooth muscle and nonmuscle actin isoforms in the human aqueous outflow pathway. Invest OphthalmolVis $S c i$ 1992;33:424-9.

48 Nakago-Matsuo C, Matsuo T, Nakago T. Intracellular calcium response to hydraulic pressure in human periodontal ligament fibroblasts. Am F Orthod Dentofac Orthop 1996; 109:244-8.

49 Arora PD, Bibby KJ, McCulloch CAG. Slow oscillations of free intracellular calcium ion concentration in human fibroblasts responding

50 Wiederholt M, Bielka S, Schweig F, Lutien-Drecoll E, Lepple-Wienhues A. Regulation of outflow rate and resistance in the perfused anterior segment of the bovine eye. Exp Eye Res 1995;61:223-34.

51 Gabelt BT, Kaulmann PL. Prostaglandin F2alpha increases uveoscleral outflow in the cynomolgus monkey. Exp Eye Res 1989;49:389-402.

52 Goligorsky MS. Mechanical stimulation induces $\mathrm{Ca}_{i}{ }^{2+}$ transients and membrane depolarization in cultured endothelial cells. Effects on $\mathrm{Ca}_{i}{ }^{2+}$ in co-perfused smooth muscle cells. FEBS Lett 1988;240:59-64.

53 Ando J, Komatsuda T, Kamiya A. Cytoplasmic calcium response to fluid shear stress in cultured vascular endothelial cells. In Vitro Cell Dev Biol 1988;24:871-7.

54 Mo M, Eskin SG, Schilling WP. Flow-induced changes in $\mathrm{Ca}^{2+}$ signaling of vascular endothelial cells: effect of shear stress and ATP. Am f Physiol 1991;260:H1698-707.

55 Schwarz G, Callewaert G, Droogmans G, Nilius B. Shear stress-induced calcium transients in endothelial cells from human unbilical cord veins. $\mathcal{f}$ Physiol 1992;458:527-38.

56 Naruse K, Sokabe M. Involvement of stretch-activated io channels in $\mathrm{Ca}^{2+}$ mobilization to mechanical stretch in endothelial cells. Am ₹ Physiol 1993;264:C1037-44.

57 Ando J, Ohtsuka A, Katayama Y, Korenaga R, Ishikawa C, Kamiya A. Intracellular calcium response to directly applied mechanical shearing force in cultured vascular endothelial cells. Biorheology 1994;31:57-68.

58 Alvarado J, Murphy C, Juster R. Trabecular meshwork cellularity in primary open-angle glaucoma and nonglaucomatous normals. Ophthalmology 1984;91:564-79. 